\title{
Interactions and Cooperation in Local Production Systems: An Analysis of Inhibiting Factors Related to Specificities of Small Enterprises
}

\author{
Antonio lacono ', Marcelo Seido Nagano ${ }^{2 *}$
}

\begin{abstract}
The purpose of this article is to present some organizational and environmental factors that inhibit interactions and cooperation among several types of actors in a local production system (LPS) of small and medium-sized enterprises (SMEs). To this end an exploratory study was carried out in an embryonic LPS of farming machinery and equipment factories located in West Paraná State, Brazil. The assessment of cooperation and interaction relations in the LPS led to the identification of inhibiting factors, which were correlated to specificities of the participating enterprises. Empirical evidence demonstrated that the inhibiting factors that impacted joint interactions and actions the most are of an organizational nature and strongly related to characteristics intrinsic to the size of the enterprises under consideration.
\end{abstract}

Key words: local production system; small-sized enterprises; cooperation; interaction.

\footnotetext{
' Master in Production Engineering at University of São Paulo; E-mail: toniacono@yahoo.com.br

2 Posdoctorate at National Institute for Space Research, Professor of the University of São Paulo. Av. Trabalhador Saocarlense, 400;

Zip code: I3566-590; São Carlos-SP; Brazil; E-mail: drnagano@usp.br. Phone number: +55 (16) 3373-9428

* School of Engineering of São Carlos - University of São Paulo, Brazil
}

ISSN: 07I 8-2724. (http://www.jotmi.org)

Journal of Technology Management \& Innovation @ Universidad Alberto Hurtado, Facultad de Economía y Negocios 


\section{Introduction}

Local Production Systems (LPSs) have received increasing emphasis in organizational studies in the last decades because they can provide concrete answers to competitiveness-related challenges existing in markets with recurrent technological changes and innovations. Not only is their importance acknowledged because of increasing competitiveness of enterprises, but also because of their capacity to generate jobs generation, leading to economic and social development.

Local Production Systems, also known as Local Productive Arrangements, refer to groupings of enterprises from the same geographical region and industrial sector with related or similar capacities. By definition LPSs include enterprises of all sizes, but in reality they generally comprise small and medium-sized enterprises that are not vertically integrated. These enterprises, in turn, attract suppliers and other similar or supporting enterprises, whose presence and importance in local systems are determined by market forces alone. In addition, LPSs give rise to many local institutions and supporting enterprises (Suzigan, Furtado, Garcia, Sampaio, 2004). This definition, in turn, according to Suzigan et al, is founded on Belussi and Gottardi's (2000) and Lombardi's (2003) studies.

Igliori (200I) sustains that enterprises may gain competitiveness via cost reduction, qualitative differentiation or increased capacity to respond swiftly to changes in market demands. Other advantages may be expressed in terms of collective learning (with knowledge developed via interactions among several types of agents), economies of scale, exploration of new market segments or niches, dissemination of knowledge, and support to innovative processes.

One of the key elements that justify the relevance of geographic concentration of enterprises is the existence of economies external to the enterprise and internal to producers' agglomeration. As pointed by Garcia (2006), appropriate incidental externalities, i.e., those spontaneously generated by enterprises belonging to the same sector or segment, may increase their competitiveness.
Besides incidental external economies, joint actions and cooperation are indicated by Schmitz (1999) as other ways to boost the competitiveness of LPSs. The author believes that there is a deliberating force at work, i.e., conscious, that favors joint actions. In other words, external economies represent a small part of the benefits that conglomerates have the potential to offer to local producers, since deliberate joint actions engender competitive gains to agglomerates. In this sense, according to Garcia (2006) and La Rovere (2003), the establishment and maintenance of interactions may reinforce external economies. In turn, the reinforcement of these interactions promotes learning processes and joint actions in a LPS. However, despite the advantages deriving from cooperation, economic agents may not be motivated enough to develop cooperative ties.

Brazilian LPSs mainly comprise small-sized enterprises characterized by incipient relations with low levels of cooperation and interaction among actors (Suzigan et al., 2004). Other aspects presented by La Rovere (200I), such as lacking management capacity, low technical sophistication, little innovation, low-skilled workforce, low product quality, and lack of financial support, are also present in Brazilian small enterprises. These aspects or conditions constitute specificities that derive from the small size of these enterprises (Leone, 1999; Escrivão Filho, 1995). Therefore, the dynamics of an LPS in which small enterprises predominate is strongly connected to their specificities, and its development is directly linked to their conditions and potentialities.

Bearing in mind the relevance of cooperation relations and interactions in the environment of LPSs and the specificities of small-sized enterprises, the main purpose of this article is to identify and analyze the factors that hinder or inhibit the establishment and strengthening of cooperation and interactions among the various types of actors, in accordance with the specificities of small-sized enterprises. To this end, the article is divided into five sections, besides the introduction. Section I presents the theoretical framework on interactions and cooperation in LPSs and specificities of SMEs. The subsequent section brings some considerations about the adopted research methodology. Section 3 presents

ISSN: 07I 8-2724. (http://www.jotmi.org)

Journal of Technology Management \& Innovation (C) Universidad Alberto Hurtado, Facultad de Economía y Negocios 
the case study and the characterization of the farming machinery and equipment LPS under consideration and its participant enterprises. Section 4 shows the results of the field study, and the last section presents the final remarks.

\section{Interaction and cooperation in LPSs}

According to Schmitz (1999), incidental external economies do not suffice to explain successful productive agglomerations, however important they may be. Cooperation relations are also instrumental in explaining the power, efficacy, development, and competitiveness of these agglomerations. In addition, the physical proximity of enterprises without corresponding interactions may reduce the potential benefits of agglomerations. Interactions can modify individuals' cognitive capabilities, ideas, and representations; they affect knowledge transmission. Constant interaction allows the establishment of processes that lead to the creation of environments favorable to collective learning.

In particular, in light of growing international competition since the 1990's, Igliori (200I) remarks that it is fundamental that enterprises invest in joint actions. New products, based on diverse sciences, have been developed by integrating different technologies, which has been possible due to cooperation among various types of actors (Cassiolato, Britto, \& Vargas, 2005). Cooperation mainly seeks to meet needs that would be hard to meet were enterprises to act individually (Amato Neto, 2000). In the same way, Camagni (1993) advances some basic reasons or possible gains that motivate enterprises to pursue cooperation with the remaining agents. Cooperation also involves some characteristics such as information/learning exchanges and joint actions (Meyer-Stamer, 2002). Table I shows some of the main needs and motivations concurring to joint actions.

\begin{tabular}{ll}
\hline Needs & Motivations \\
\hline - Integrate competencies and use know-how of & - Generation of profits that could not be obtained \\
other enterprises; & independently; \\
- Share burden of doing technological research, & - More rigorous control of assets and competencies in \\
and development and knowledge obtained; & order to make innovation processes possible. \\
- Offer higher quality products and more & - Synergic economies of scale in production, marketing \\
diversified lines; & and R\&D activities. \\
- Increase competitiveness for external market & - Strengthening of capacity to respond to external \\
insertion; & shocks. \\
- Strengthen purchasing capacity. & - Control over promising markets. \\
- Share resources, particularly underutilized ones; & - Economies of scope and reinforcement of product \\
- Share risks and costs to create new & differentiation. \\
opportunities. & - Reduction and rationalization of R\&D operating cost. \\
\hline
\end{tabular}

Source: Based on Amato Neto (2000) and Camagni (1993)

Table I - Needs and motivations conducive to development of joint actions.

Although cooperation presents innumerable advantages, economic actors may not be motivated enough to develop cooperative ties. According to Meyer-Stamer (2002), businessmen' main reasons for opting for solitary actions are competition, macroeconomic conditions, transaction costs, trust and business culture.
Competition: Businessmen often resist cooperation because they see other enterprises in the same sector as competitors. Hence, they prefer to avoid closer relations to protect their business secrets.

Macroeconomic conditions: Some macroeconomic conditions may dissuade cooperation among

ISSN: 07I 8-2724. (http://www.jotmi.org)

Journal of Technology Management \& Innovation (C) Universidad Alberto Hurtado, Facultad de Economía y Negocios 
enterprises, such as high taxes, macroeconomic instability, and constantly changing "game rules".

Transaction costs: Despite being capable of reducing transaction costs, cooperation may also create them. It seems natural that more involvement in relations should give rise to more conflicts, which demands effort and time for enterprises to solve them. Therefore, there may discrepancies between incentives to cooperate and desired cooperation intensity.

Trust and business culture: An environment of vertically integrated enterprises where failures and predatory behaviors have been common-place promotes a business culture characterized by isolation and low levels of trust. These failures may promote the idea that cooperation is unfeasible and hinder the possibility of future efforts towards encouraging cooperation.

Nevertheless, it is important to remark that, besides the aforementioned motivations, small enterprises may have additional reasons, related to specificities inherent to their size, for not pursuing joint actions, which must be taken into account when analyzing cooperative interactions and relations.

\section{Specificities of small enterprises}

For a long time the dynamics of small enterprises has been analyzed and theorized as if they were large enterprises. This paradigm has led small enterprises to adopt management practices, techniques and principles that are not adequate to their reality (Escrivão Filho et al., 2005). Organizational theories are essentially grounded on problems from large enterprises, which means that they cannot be extended to small and medium-sized enterprises because the latter have different characteristics (Leone, 1999). This is corroborated by Lemos (2003), who claims that smallsized enterprises should not be indistinctly treated because their universe is extremely diverse and their promotion and development imply the formulation of tools that suit a great variety of profiles. Thus, there are no organizational theories that address the distinct dynamics and problems of SMEs and that can advance specific management models.
Escrivão Filho (1995) proposes a classification of specificities of small enterprises based on a model of organization, founded on business administration theories, that evidences internal and external aspects. Internal specificities, i.e., organizational specificities, are divided into structural, behavioral, decisional, strategic, and technological specificities. On the other hand, external aspects are environmental specificities. The types of specificities of small enterprises are described below, according to Escrivão Filho et al (2005); Migliato \& Escrivão Filho (2004); Bigaton \& Escrivão Filho (2006).

Environmental specificities: Aspects external to enterprises, i.e., how macro-environmental forces influence their management and performance. These forces may be economic, social, legal-political and technological. In the case of small enterprises these forces are important in that they have little or no control over the environment in which they operate. Examples of environmental factors are those related to fiscal legislation, financing, taxes, economic models, interest rates, etc.

Behavioral specificities: Aspects related to the behavior of enterprise people in terms of values, motivations, competencies, and leadership styles. They aim at understanding the behavior of small businessmen as regards their tendency to be either entrepreneurs or business managers. Examples of environmental factors are business visions, management styles, and organizational cultures.

Decisional specificities: Aspects related to decisionmaking processes involving enterprise problems and opportunities. They encompass strategic, administrative and operational decisions, individual or collective decisions, programmed or not programmed decisions, and rational or intuitive decisions. Examples of this group of specificities are paternalism, management style, and management knowledge.

Technological specificities: They refer to technological characteristics of enterprises, and the way they produce and make use of technologies in their processes. They involve process and service technologies, technological innovations, and information technologies. Examples of

ISSN: 07|8-2724. (http://www.jotmi.org)

Journal of Technology Management \& Innovation @ Universidad Alberto Hurtado, Facultad de Economía y Negocios 
these factors are: technology modernization, availability of technological resources, and product and process innovations.

Structural specificities: These specificities relate to how activities are divided, organized, and coordinated at small enterprises. Examples of these factors are flexibility, agility, formalization, labor division, workforce qualification, and organization of technical and administrative functions.

Strategic specificities: These aspects refer to enterprises' internal and external vision and how strategies are developed. Some examples of these specificities are strategy formalization and planning, market types and reach, and programming of products and target-markets.

\section{Research method}

In order to study and analyze interactions and cooperation relations among diverse agents of the farming machinery and equipment LPS under investigation the case-study method was adopted, which was carried out by means of interviews, in loco observations, and document analysis. Data were collected at 17 micro, small, and medium-sized enterprises in 2008. The case selection was intentional, deriving from studies developed by Rede APL Paraná (a network to support local productive arrangements in Paraná State, Brazil). It was based on the method of identification and characterization of LPSs described by Suzigan et al. (2004). Rede APL is composed by Paraná State agencies and national institutions.

The interviews, considered as a vital source of information in case studies, were carried out face-toface at enterprises and institutions belonging to the LPS in question. Respondents were businessmen and institution directors (class organizations, associations and universities). Two questionnaires were used: one related to general and structural characteristics of the arrangement, and another to characterize producers. The questionnaire used at the enterprises was subdivided into three modules: (i) identification of general aspects of enterprises; (ii) characterization of profile of enterprises and owners; (iii) identification of inhibitors of relations among enterprises and between enterprises and institutions.

The LPS under investigation may be characterized as a productive arrangement embryo according to the typology proposed by Suzigan et al. (2004). This arrangement was selected because this type of LPS demands greater analytical effort and presents more prominent structural characteristics and incipient ties. In order to identify inhibiting factors the questionnaire was formulated so as to initially identify the cooperation spaces and then to characterize and analyze the relations among enterprises and between enterprises and institutions. This initial phase, i.e., identification of spaces, is considered in this study to be of great importance because cooperation spaces are the raison d'être of these relations.

\section{The case of the farming machinery and equipment LPS in West Paraná State}

\section{I Characterization of LPS}

The LPS of farming machinery and equipment factories encompasses several municipalities of two microregions in West Paraná State, Brazil,, including the towns of Cascavel and Toledo. Its origin remounts to the region's colonization process, but from the 1970's on modernization of farming processes altered its technological base. This LPS does not have a single key product; several products are produced. This characterizes a heterogeneous structure. Micro, small and medium-sized enterprises, of national capital, constitute this agglomeration. The main products of this LPS are harvesting and pre- and post-harvesting machinery and equipment. Its market is predominantly national, with strong a regional reach and little external participation (just $2.5 \%$ ). The LPS displays a considerable educational and institutional infrastructure. The educational infrastructure comprises 14 universities with a total of 30,000 students. As regards the institutional infrastructure, it includes supporting institutions, associations and unions.

ISSN: 07 I 8-2724. (http://www.jotmi.org)

Journal of Technology Management \& Innovation (c) Universidad Alberto Hurtado, Facultad de Economía y Negocios 


\subsection{Characterization of LPS enterprises}

Aspects such as workforce profile, competitive capacity and productive and commercialization structures were considered to characterize the enterprises belonging to the LPS, as shown below. The study investigated a sample of 17 enterprises with 385 direct job positions. This number includes 10 micro enterprises, 6 small enterprises and I medium-sized enterprise. With respect to management type, II enterprises were family-managed, 5 professionally managed, and just one enterprise was managed by its major partner.

Workforce profile: Low qualification, particularly on the shop floor; administration personnel is better qualified.

A great number of workers work in both areas: production and administration. Despite the region having a good educational infrastructure, which integrates several fields of knowledge, there is a shortage of courses on more specific subjects, especially concerning the production area of enterprises.

Competitive capacity: Product quality and capacity to introduce new products/processes were the main competitiveness factors. On the other hand, price and commercialization strategies were considered to be of little relevance to competitiveness. The technological level of products also ranked low in importance, since the market in which the enterprises operated did not demand that they incorporate more technologies into their products.

Production and commercialization structure: Predominance of micro and small enterprises; most of them were established less than 25 years ago. The LPS produces a great variety of products, encompassing several market niches. The main commercialization channels were direct sales and commercial representation. The most important factors in the commercialization process were product price and brand name, and enterprise tradition. On the other hand, the least important factors were marketing and advertising, post-sales services, and technological level of product.

Externalities: On the whole, businessmen did not see many advantages to belonging to a LPS. The main difficulty found was access to qualified workforce. The most cited advantages were customers' proximity and low cost workforce.

\section{Results}

In order to identify and analyze the factors that inhibit interaction and cooperation relations, this study considered the perspectives of the businessmen about their products, markets, and business. These elements were chosen as starting points to guide the identification of cooperation spaces for arrangement agents and subsequently detect factors that inhibit potential joint actions. The arrangement actors cited by the businessmen were: suppliers, customers, competitors, consulting firms, other enterprises from the same sector, universities, research institutes, professional training centers, business associations, and financial institutions. Universities were cited as the most desired partners in product marketing, followed by competitors, professional training centers, and enterprises from other sectors. Suppliers, customers, financial institutions, consulting firms, and business associations were mentioned by one third of the enterprises investigated. Research institutes were the least cited, by one fourth of the enterprises.

The elements that hinder or inhibit proximity or, in many cases, attempts to promote interaction and cooperation among LPS actors are described below for each cited actor. Firstly, some enterprises reported having had partnership experience with universities, but their contribution had been limited to improving project ideas. It is important to remark that failed experiences lead enterprises to mistrust or doubt the technical expertise of universities. Another point advanced by the respondents was the existence of conflicting interests, i.e., some enterprises claimed that universities were indifferent to their problems; they were more interested in pursuing their research work. Lack of trust was also cited as an obstacle to partnerships. Academic ambitions seem to have promoted businessmen's insecurity. On the other hand, businessmen were not knowledgeable about intellectual property laws and rules. In addition, scarce information about potential partnerships with universities was one of the most cited

148

ISSN: 07 I 8-2724. (http://www.jotmi.org)

Journal of Technology Management \& Innovation (C) Universidad Alberto Hurtado, Facultad de Economía y Negocios 
factors by respondents. When asked about technical resources and knowledge available at universities, some businessmen said they did not know of them and thus did not seek them. Many businessmen said that they did not have time to learn about universities and to seek partnerships with them. The activities carried out at the enterprises were reported to be overtaxing, which left them with little time for information seeking.

As regards suppliers, some enterprises claimed not to have the capital needed to create partnerships to improve their products or that they had no information to persuade suppliers to establish partnerships. Nevertheless, the enterprises acknowledged the importance of interacting with suppliers and the potential that suppliers represented to the development of their products. Another point is related to qualified workforce; most enterprises did not have staff with adequate qualification to interact with suppliers as regards product development. Also, there were problems regarding facilities: some enterprises indicated that insufficient equipment and inadequate space were barriers to joint actions. In addition, in spite of acknowledging that joint actions could help them to solve problems, some of the businessmen had never approached their suppliers. In this case, fear of losing the exclusiveness in supplies was seen as a chief cause.

With respect to competitors, unwillingness toward joint actions is more evident. Some enterprises limit their actions to borrowing material and sharing machinery and equipment. Actions aimed at developing products were less common because businessmen feared losing markets and not drawing any benefits from working with competitors. Besides, owing to the fact that some potentialities are of great magnitude, most enterprises claimed that they did not have enough know-how or capability to develop joint actions. Also, there were enterprises that had never approached their competitors and some of them did not even know their direct competitors.

With reference to customers, it is important to remark that the businessmen considered them to be sources of information necessary for learning. Nonetheless, some enterprises claimed not to seek partnerships with customers because they had no available staff and, for some actions, qualified workers. Many enterprises sought customers with cooperation potential outside of the LPS.

Some inhibitions and difficulties were associated with enterprises from the same sector, such as lack of trust owing to previous unsuccessful experiences, and shortage of resources and staff. A point of interest is that most respondents had never thought about the possibility of establishing partnerships with other enterprises; some had never sought them and others had no knowledge of them. Lack of time, initiative, and capital were also cited by some enterprises as barriers to partnering with other enterprises from the same sector. For instance, one of the LPS enterprises had to give up the development of a product because of rising cost, in spite of its being shared with other enterprises.

Generally speaking, consulting firms are not seen as potential partners. Some enterprises claimed that they had little information about these firms. One of enterprises under investigation declared that, despite having confidence in consulting firms, they did not have enough money to invest in partnerships with them. On the other hand, interactions seem to take place very frequently in the LPS concerning professional training centers. These agencies are highly regarded by the enterprises. Some of them are partly assisted by professional training centers and they claimed that there was room for growth in these relations.

With regard to business associations, there appears to be shortage of information; some enterprises did not know exactly what these institutions could offer them. Other enterprises claimed that they were knowledgeable about their services. However, they did not interact much because their needs had not been met on previous occasions. In addition, Financial institutions were seen as important partners by the enterprises. Notwithstanding, there are some barriers to strengthen relations with these agents. The greatest barriers were: high interest rates and the amount offered, which was not enough to cover the necessary investments according to the businessmen.

ISSN: 07I 8-2724. (http://www.jotmi.org)

Journal of Technology Management \& Innovation (C) Universidad Alberto Hurtado, Facultad de Economía y Negocios 
Finally, few enterprises acknowledged how important and necessary it is to establish partnerships with research institutes. Even when this importance was recognized there was the obstacle of not being able to provide qualified staff. There is also lack of knowledge about possible joint actions and access difficulties. From the businessmen's statements it is possible to gather some elements regarding relations among the enterprises and between the enterprises and other institutions within the LPS. Table 2 shows some factors that inhibit or hinder more intense interactions and the development of joint actions.

\begin{tabular}{|c|c|}
\hline Inhibiting factors & Description \\
\hline Lack of information & $\begin{array}{l}\text { Lack of information, whether about enterprises and institutions or about interaction } \\
\text { and cooperation benefits, is present in most enterprises. Despite some improvement, } \\
\text { concepts such as agglomeration, partnership, and interaction must be better } \\
\text { understood. }\end{array}$ \\
\hline $\begin{array}{l}\text { Shortage of capital or } \\
\text { human resources }\end{array}$ & $\begin{array}{l}\text { Some enterprises are willing to interact and develop joint actions, but lack of capital } \\
\text { causes difficulties, especially when it comes to product development. }\end{array}$ \\
\hline $\begin{array}{l}\text { Low qualification and } \\
\text { unavailability of } \\
\text { workforce }\end{array}$ & $\begin{array}{l}\text { Low qualification or unavailability of qualified workforce create obstacles to } \\
\text { partnerships with suppliers, universities and research institutes with respect to new } \\
\text { product development. }\end{array}$ \\
\hline $\begin{array}{l}\text { Difficulties in } \\
\text { accessing universities }\end{array}$ & $\begin{array}{l}\text { Some enterprises claimed that professors and technical departments were not } \\
\text { accessible and too bureaucratic, and that contacting these actors could take too much } \\
\text { time. }\end{array}$ \\
\hline $\begin{array}{l}\text { Facilities and } \\
\text { equipment }\end{array}$ & $\begin{array}{l}\text { Some enterprises do not possess adequate facilities and equipment to develop joint } \\
\text { activities. They lack organizational resources. }\end{array}$ \\
\hline Organizational culture & $\begin{array}{l}\text { Some enterprises pointed to previous unsuccessful experiences and that they had } \\
\text { engendered insecurity and promoted the belief that partnerships did not work. }\end{array}$ \\
\hline Lack of confidence & $\begin{array}{l}\text { This factor appears especially as regards competitors, but it was also cited as regards } \\
\text { potential partnerships with universities. In this case, they reported insecurity as regards } \\
\text { intellectual property. }\end{array}$ \\
\hline $\begin{array}{l}\text { Limited } \\
\text { capacity/competencies } \\
\text { of local enterprises }\end{array}$ & $\begin{array}{l}\text { Many of the partnerships and interactions are not established or strengthened because } \\
\text { local enterprises are small and have technological limitations. More technologically } \\
\text { developed enterprises could agglomerate more easily. }\end{array}$ \\
\hline $\begin{array}{l}\text { Conflicting interests } \\
\text { between institutions } \\
\text { and enterprises }\end{array}$ & $\begin{array}{l}\text { A conflicting case cited by an enterprise involved higher education institutions. It } \\
\text { appears that if projects do not meet areas of interest of these institutions, partnerships } \\
\text { do not occur. }\end{array}$ \\
\hline $\begin{array}{l}\text { Absence of a holistic } \\
\text { business vision }\end{array}$ & $\begin{array}{l}\text { There is a weak perception of all the elements of the enterprise on the part of the } \\
\text { businessmen. There seems to be partial visions mainly related to the businessmen's } \\
\text { areas of knowledge. }\end{array}$ \\
\hline
\end{tabular}


Accumulation of functions by

businessmen

Use of obsolete technologies

High interest rates
Most of the businessmen under investigation accumulated technical and managerial functions. This situation left them with little time to think up strategies and pursue partnerships.

Several enterprises declared that they had no technologically advanced machinery and equipment. According to some respondents, resources based on simple technologies made it difficult for enterprises to cooperate and propose joint actions to develop or improve products.

High interest rates together with low availability of funds are the main obstacles to the establishment of partnerships with financial institutions.

Source: Based on data gathered by the authors of this study

Table 2 - Factors that inhibit LPS interactions and cooperation.

The identification of factors that inhibited interactions and joint action in the arrangement in question pointed to their characteristics. Generally speaking, these characteristics are related to the specificities of small enterprises (Table 3).

\begin{tabular}{ll}
\hline Inhibiting factors & Description \\
\hline Structural specificities & $\begin{array}{l}\text { Lack of organizational resources; Inadequate facilities and equipment; } \\
\text { Low qualification of workforce; Shortage of workforce; }\end{array}$ \\
$\begin{array}{l}\text { Accumulation of functions by businessmen; Constrained } \\
\text { organizational structure; Minimal organizational structure; Little time } \\
\text { for strategic decision-making. }\end{array}$ \\
Technological specificities & $\begin{array}{l}\text { Obsolete technologies; Low rate of technological modernization; } \\
\text { Fehavioral specificities }\end{array}$ \\
Enterprises lack holistic vision; Organizational culture; \\
Strategic specificities & Little initiative; Lack of trust. \\
Decisional specificities & Insufficient time for planning; Meager knowledge of markets. \\
Environmental specificities & Lack of ability to manage time.
\end{tabular}

Source: Results from the field investigation by the authors of this study

Table 3 - Inhibiting factors related to specificities of investigated enterprises.

\section{Final remarks}

This study sought to identify and analyze factors that inhibit interactions and cooperation among diverse types of actors present in an embryonic local production system. Firstly, it is important to make some preliminary remarks about spatial, technological and social dimensions of the LPS. As regards the spatial

ISSN: 07I 8-2724. (http://www.jotmi.org)

Journal of Technology Management \& Innovation (c) Universidad Alberto Hurtado, Facultad de Economía y Negocios 
dimension it was verified that LPS can make use of the existing infrastructure to its advantage. However, it should be emphasized that, despite its territory displaying a significant institutional, educational and scientific-technological infrastructure, the relations in the LPS were shown to be incipient and its resources seldom shared. The existence of this infrastructure has not been enough to promote significant joint actions on the part of the LPS actors. When these actions occur, they are usually reduced to mere information exchange and joint actions of an operational nature.

As regards the technological dimension, it was possible to attest that the group of enterprises has the capability to increment product and process innovations. However, these enterprises present difficulties deriving from limited financial, human, technical, and managerial resources. These constraints hinder interactions and joint actions with other enterprises and institutions. Concerning the social dimension, it is clear that some supporting and coordinating institutions have worked hard to promote cooperation among the LPS actors. However, these actions only encompass some of the enterprises of the arrangement and the activities meet part of their needs. As regards the inhibiting factors presented by the enterprises, it is possible to notice that their characteristics are strongly associated with behavioral and structural specificities, generally caused by deficient business management practices and lack of several types of resources.

It was also verified that potential interactions and joint actions may be compromised and curtailed by issues related to the enterprises' infrastructure and management practices. This means that, even when willing to develop joint actions or more intensive interactions with other arrangement actors, the enterprises face barriers associated with technical, human, and financial resources. In other words it is possible to argue that factors that inhibit the establishment/strengthening of joint actions are clearly related to specificities of enterprises of the same size. Therefore, while public policies for the promotion of LPSs of small and medium-sized enterprises should take into account the specificities of their cultural, regional, economic and social contexts, it is vital that they also take into consideration specificities inherent to small enterprises if they are to succeed in promoting relations and joint actions.

\section{References}

AMATO Neto, J. (2000). Redes de cooperação produtiva e clusters regionais: oportunidades para as pequenas e médias empresas. Atlas, São Paulo.

BELUSSI, F. \& Gottardi, G. (2000). Evolutionary Patterns of Local Industrial Systems: towards a cognitive approach to the industrial district. Aldershot, Ashgate,.

BIGATON, A.L.W., \& Escrivão Filho, E. (2006). Especificidades organizacionais da pequena empresa: um estudo no setor metal-mecânico de São José do Rio Preto. Anais do XIII SIMPEP, Bauru, SP, Brasil.

CAMAGNI, R. (1993). Inter-firm industrial networks: the costs and benefits of cooperative behaviour. Journal of Industrry Studies, I (I), I-I6.

CASSiOlATO, J. E., Britto, J. N. P., \& Vargas, M. A. (2005). Arranjos cooperativos e inovação na indústria brasileira. In: De Negri, J. A., \& Salerno, M. S. (Orgs.) Inovações, padrões tecnológicos e desempenho das firmas industriais brasileiras. IPEA, Brasília.

ESCRIVÃO Filho, E. (1995). A natureza do trabalho do executivo. Tese de doutorado, Universidade Federal de Santa Catarina, Florianópolis, SC, Brasil.

ESCRIVÃO Filho, E. et al. (2005). Compreendendo a dinâmica das pequenas empresas: mapa organizacional como ferramenta da ação administrativa. Revista Matiz, Matão, I (I), 20-40.

GARCIA, R. (2006). Economias externas e vantagens competitivas dos produtores em sistemas locais de produção: as visões de Marshall, Krugman e Porter. Ensaios FEE, 27 (2), 30I-324.

IGLIORI, D.C. (200I). Economia dos clusters industriais e desenvolvimento. São Paulo: Iglu.

ISSN: 07 I 8-2724. (http://www.jotmi.org) 
LA ROVERE, R. L. (200I). Perspectivas das micro, pequenas e médias empresas no Brasil. Revista de Economia Contemporânea , 34 (número especial), 137 -

154.

LEMOS, C. (2003). Micros, pequenas e médias empresas no Brasil: novos requerimentos de políticas para a promoção de sistemas produtivos locais. Tese de doutorado, Universidade Federal do Rio de Janeiro, Rio de Janeiro, RJ, Brasil.

LEONE, N.M.C.G. (1999). As especificidades das pequenas e médias empresas. Revista de Administração, 34 (2), $91-94$.

LOMBARDI, M. The evolution of local production systems: the emergence of the "invisible mind" and the evolutionary pressures towards more visible "minds". Research Policy, v.32, n.8, p. I443-I462, 2003.

MEYER-STAMER, J. (2002). Clustering and the Creation of an Innovation-Oriented Environment for Industrial Competitiveness: Beware of Overly Optimistic Expectations. International Small Enterprise Journal, 20 (3).

MIGLIATO, A. L. T., \& Escrivão Filho, E. (2004). A Pequena Empresa e suas Especificidades: Uma Proposta de Classificação Fundamentada em um Modelo de Concepção Organizacional. Anais do VII Seminários em Administração - SemeAd, São Paulo, SP, Brasil.

SCHMITZ, H. (1999). Collective efficiency and increasing returns. Cambridge Journal of Economics. 23 (4), 465-483.

SUZIGAN, W. ; Furtado, J. ; Garcia, R.C.; Sampaio, S. E. K. (2004). Local Production Systems in Brazil: Mapping, Typology and Policy Suggestions. In: The 44th European Congress of the Regional Science Association. Porto, Portugal, (I), p. 20-40. 